\title{
Happiness and economic freedom: Are they related?
}

\author{
Ilkay Yilmaz ${ }^{1, \mathrm{a}}$, and Mehmet Nasih $\mathrm{Tag}^{2}$ \\ ${ }^{1}$ Mersin University, Department of Economics, Mersin University, 33342 Mersin, Turkey \\ ${ }^{2}$ Mersin University, Department of Business Administration, Mersin University, 33342 Mersin, Turkey
}

\begin{abstract}
In this article we investigate the linkage between economic freedom and happiness (subjective well-being). We attempt to understand which economic institutions (rule of law, limited government, regulatory efficiency, open markets) have influence on subjective well-being. For this purpose we use a panel dataset and analyze the effect of economic freedom on subjective well-being while using various control variables such as government expenditures as percentage of GDP, human development, social support, freedom of choice and generosity. Our pooled FGLS estimations indicate that all pillars of economic freedom have a strong influence on the average subjective well-being in society. Three of these pillars, namely rule of law, regulatory efficiency and open markets, positively affect subjective well-being. To our surprise we have found a negative relationship between limited government and subjective wellbeing. This might be due to the situation that reducing the size of government possibly leads to lower government expenditures and higher unemployment, which in turn results in lower subjective well-being.
\end{abstract}

\section{Introduction}

As the great Austrian economist Ludwig von Mises explained in his magnum opus, human action can be defined as the striving for happiness. When people act, they act in order to satisfy their desires. Therefore it is not erroneous to say that individual judgments of value are the only standard of satisfaction, though people's judgments of value may be different from each other and they might even differ for the same individual at different times. Things that make a person happy or unhappy completely depend on his/her own will and judgment, his/her personal and subjective valuation (Mises, 1998, p. 14) [1].

These statements do not imply in any way that people only think for themselves in life. There have always been and will be people who work and struggle mainly to improve the conditions in which other people live. Actually, it is impossible to find a person whose happiness is not affected by the well-being of some other people. Not only our own troubles, but also the troubles of those whom we know and care for make us uneasy. We tend to be happy when people whom we love are also happy. Nevertheless these considerations do not alter the fact that how happy one feels in a given set of conditions depends on one's own subjective valuation. There is no objective measurement of happiness. Happiness, by definition, is subjective well-being.

In this paper we study the relationship between economic institutions and happiness (subjective wellbeing). We try to determine which economic institutions,

\footnotetext{
a Corresponding author: ilkayyilmaz@mersin.edu.tr
}

if any, increase the level of subjective well-being in a country. The literature on the relationship between economic institutions and economic growth suggests that good governmental institutions foster economic growth as in the studies of Rodrik, Subramanian and Trebbi (2004) [2], Acemoglu, Johnson and Robinson (2005) [3], Keefer and Knack (2007) [4] and Rodrik (2008) [5]. One might think that institutions, positively affecting the material well-being of a society, must also increase the happiness of that society. As stated in Bjornskov, Dreher and Fischer (2010, p. 420), the literature on the relationship between economic institutions and subjective well-being, on the other hand, is quite limited and earlier works in this field are not very conclusive [6]. In their study Bjornskov, Dreher and Fischer find that in poor countries the effects of economic-judicial institutions on subjective well-being are more important than those of political institutions.

However, results of two recent works in this field are quite unequivocal; authors find a strong positive relationship between economic freedom and subjective well-being. The study made by Rode, Knoll and Pitlik (2013) arrives to the conclusion that economic and political freedom make people happy through two channels [7]. First, free markets and probably also democracy increase economic growth and decrease unemployment, thereby also increasing the level of happiness in the society. Second, risk aversion and freedom of choice are values in themselves and make people happy. Pitlik, Redin and Rode (2015) paper, on the other hand, emphasizes that economic freedom 
increases individual happiness by increasing the feeling of control that people experience in life and also by giving them the freedom to choose between different options in various markets [8].

The remainder of this paper is organized as follows. In the next section we describe the model specification and the estimation procedure as well as the data used in the study. Results are presented and interpreted in Section 3. The final section concludes the paper.

\section{Data and Methodology}

\subsection{Sample and Data}

In this paper, we attempt to analyze and understand the sources of subjective well-being of the national level. Along with the increasing interest among researchers in this subject, there have been several attempts to measure subjective well-being of the national level, or happiness. One of the widely used measures utilizes data from Gallup World Poll (GWP) survey. Since 2005, GWP survey includes a life evaluation question that measures happiness. In our analyses, we utilize data on this question as well as other measures of social environment from the same survey. We construct our sample by combining GWP survey data with macroeconomic indicators from World Bank's World Development Indicators (WDI), United Nations' Development Program's (UNDP) data on human development, and Heritage Foundation's data on economic freedom. Although the WDI and economic freedom data that we use in our analyses are available since 1995, our sample period is limited by the years covered in the GWP data, and human development data, which are available for the period between 2008 and 2013. Thus, our final sample includes one-year observations of 639 countries, and the observation of 137 countries for the period between 2008 and 2013.

\subsection{Empirical Specification and Measures}

The related literature provides several explanations with regard to the variance in subjective well-being of the national level. These explanations could be broadly classified into three sub categories: economic, social and institutional. So far, perceived corruption and democratic institutions have received the most attention among institutional explanations. On the other hand, there have been few studies relating institutions of economic freedoms to subjective well-being of the national level. Thus, in our empirical analyses we focus our attention on how a cross-country variation in economic freedoms is related to subjective well-being of the national level. Our empirical specification is stated as follows:

$$
\mathrm{SWB}_{\text {it }}=\alpha+\mathbf{x}_{\text {it }}^{\prime} \boldsymbol{\beta}+\delta \mathrm{z}_{\mathrm{it}}+\mathrm{u}_{\mathrm{it}}
$$

where SWB is a country level measure of happiness or subjective well-being; $\alpha$ is a constant; $\mathbf{x}^{\prime}$ is a vector of economic and social control variables at the country level that includes government expenditures as percentage of GDP, unemployment, human development index, social support, freedom to express life choices, and generosity; $z$ is an institutional variable that could be one of the four dimensions of economic freedom; $u$ is the error term with mean zero and assumed to be uncorrelated with the right-hand side covariates in the model. Below we describe the measures for these variables.

Subjective well-being is our national level measure of average happiness on a scale from 0 to 10 and is based on the following question from GWP survey: "Please imagine a ladder, with steps numbered from 0 at the bottom and to 10 at the top. Suppose we say that the top of the ladder represents the best possible life for you and the bottom of the ladder represents the worst possible life for you. On which step of the ladder would you say you personally feel you are standing at this time, assuming that the higher the steps, the better you feel about your life, and the lower the steps the worse you feel about it? Which step comes closest to the way you feel?"

As noted, our main interest in this paper is how economic freedoms are related to subjective well-being. Economic freedoms are defined as the right of an individual to control what s/he does with his/her own labor and property. One of the well-known assessments of institutions of economic freedom is provided by Heritage Foundation's Index of Economic Freedom. This index is calculated by assessing ten institutions on a scale from 0 to 100 . These institutions include property right protection, freedom from corruption, fiscal freedom, government spending, business freedom, labor freedom, monetary freedom, trade freedom, investment freedom and financial freedom. Following the index's methodology, we aggregate the measures on these institutions to obtain what we call four pillars of economic freedom. These pillars are the rule of law, limited government, government efficiency and open markets. Rule of law is obtained by taking the average of a country's scores on property rights protection and freedom from corruption. Limited government is calculated by taking the average of a country's scores on fiscal freedom and government spending. Regulatory efficiency is calculated by taking the average of a country's scores on business freedom, labor freedom and monetary freedom. Finally, market openness is calculated by taking the average of a country's scores on trade freedom, investment freedom and financial freedom.

As discussed previously, social and economic factors as well are likely to be closely related to subjective wellbeing. Thus, following the related literature, we consider additional explanatory variables in our econometric analyses. Three of these control variables are based on World Happiness Report (2013, 2015), which employs GWP survey data to rank world countries with respect to happiness. Social support is intended to capture people's perception of whether they have someone to count on during times of trouble. Specifically, this variable is measured by taking the national-level average of either 0 (no) or 1 (yes) responses to the following question: "If you were in trouble, do you have relatives or friends you can count on to help you whenever you need them, or not?" The second variable, the freedom of choice is 
measured by taking the national average of either 0 (no) or 1 (yes) responses to the following question: "Are you satisfied or dissatisfied with your freedom to choose what you do with your life?" Finally, the third variable, generosity, is equal to the residuals that are obtained by regressing the national average of either 0 (no) or 1 (yes) responses to the GWP question "Have you donated money to a charity in the past month?" on GDP per capita.

Another important determinant of subjective wellbeing is likely to be the level of human development achievement in a country. Human development is the process of expanding as well as achieving the level of people's opportunities "to lead a long and healthy life, to be educated and to enjoy a decent standard of living." (Human Development Report 1990, UNDP, Oxford University Press) [9]. This concept is measured by the human development index (HDI), which aggregates national level indicators of health, income and education. More specifically, the human development index for a country is the aggregate value of equally weighted values of life expectancy at birth, GDP per capita, and education, where the value of education is constructed by taking one third of the tertiary gross enrolment rate and two third of the literacy rate.

Finally, we consider two control variables that are related to the macroeconomic environment. One of these variables is government expenditures (as percentage of $G D P$ ) which is the value of government final consumption expenditures divided by GDP. This value includes all government current expenditures for purchases of goods and services and compensation of government employees. The other variable, unemployment, is the level of unemployment in a country. The data on both of these variables come from WDI.

Since economic freedom fosters conditions suitable for higher HDI and lower unemployment levels, in order to calculate the full (direct and indirect) impact of economic freedom variables on subjective well-being, we apply a methodology used by Gwartney, Holcombe and Lawson (2006) [10] and Rode, Knoll and Pitlik (2013) [7]. We first estimate the independent impact of our basic model on HDI (we consider HDI with all other independent variables in Equation 1) and on the unemployment rate (we calculate the unemployment rate depending on all other independent variables in Equation 1) and then we use the residuals from both estimations to explain subjective well being in Equation 1.

\subsection{Estimation Technique}

In order to test the empirical model, the pooled OLS estimation technique can be used. Assuming that the error term and independent variables are uncorrelated, pooled OLS would produce consistent estimates. On the other hand, using pooled FGLS or population-averaged estimation, more efficient estimates can be obtained compared to pooled OLS. Under this estimation technique, individual effects are assumed to be random, and, hence, they are averaged out (Cameron and Trivedi,
2009) [11]. Therefore, we obtain all our estimates using the pooled FGLS estimation with robust standard errors.

\section{Results}

It is worth exploring the bivariate correlations in our data before we proceed to regression analyses. Table 1 and Table 2 present some summary statistics and the correlations matrix, respectively. Note that the average subjective well-being is around 5.5, slightly above the middle point of the scale. Given a standard deviation of 1.13 , it looks like there is a considerable variation among world's nations with respect to how happy they think they are. Thus, it is important that we explore the determinants of these variations. From the correlations matrix we observe that pillars of economic freedoms are strongly related to subjective well-being. We now move beyond simple bivariate correlations and explore this relationship using population averaged panel data estimates.

Table 3 presents the population averaged estimates (models) of our empirical specification. All estimates include controls for year effect. Also, the standard errors reported in all estimates are adjusted for clustering on countries. Model 1 presents estimates of our empirical specification excluding measures of economic freedoms from the right hand side. All variables are significantly related to subjective well-being. Moreover, all coefficients have the expected sign. The other estimates (models) in Table 3 give the estimates of our empirical specification by including a single pillar of economic freedoms at a time.

Model 2 presents the estimate when the rule of law is in the model. The results are consistent with our expectation. It appears that subjective well-being goes up as a rule of law increases $(\mathrm{p}<0.001)$. More specifically, holding everything else fixed, one standard deviation increase in the rule of law is associated with 0.44 standard deviation increase in subjective well-being. As the average rule of law around the world is relatively low, it appears that there is a significant promise of improving subjective well-being by focusing on enhancing protections for property rights and reducing corruption.

Model 3 presents the estimate when a limited government is in the model. According to this estimate, the sign on the coefficient of the limited government is not consistent with our expectation. It appears that all else fixed, as the limited government goes up, subjective well-being goes down $(\mathrm{p}<0.001)$. That is, shrinking the size of the government (i.e., reducing the tax burden on citizens) seems to be negatively related to subjective well-being. Examining the bivariate correlations between the limited government and our macroeconomic data could provide an explanation for this finding. Note that there is a high negative correlation between government expenditures and the limited government. Moreover the correlation between the limited government and unemployment is also negative. Thus it is possible that reducing the size of the government leads to lower government consumption expenditures and higher 
unemployment, which in turn results in lower subjective well-being.

Model 4 presents the estimate of our empirical model when regulatory efficiency is in the model. It is consistent with our expectation that the higher the regulatory efficiency is, the higher is subjective wellbeing $(p<0.001)$. More specifically, one standard deviation increase in regulatory efficiency is associated with 0.28 standard deviation increase in subjective wellbeing. This result suggests that government attributes such as efficient regulation of businesses, work and labor market as well as price stability along with low price controls are closely related to subjective well-being.
Finally, Model 5 presents the estimate of our empirical model when the open markets variable is in the model. We expected that this variable is positively related to subjective well-being. Being consistent with this expectation, we find that one standard deviation increase in open markets is associated with 0.21 standard deviation increase in subjective well-being $(\mathrm{p}<0.001)$. Thus, it appears that open markets which are characterized by the ease of international trade and investment are positively related to subjective wellbeing.

Table 1. Summary Statistics

\begin{tabular}{|l|c|c|c|}
\hline Variables & Observations & Mean & Std. Deviation \\
\hline Subjective Well Being & 1,077 & 5.463 & 1.133 \\
\hline Rule of Law & 3,374 & 44.087 & 22.698 \\
\hline Limited Government & 3,374 & 68.335 & 17.393 \\
\hline Regulatory Efficiency & 1,888 & 66.470 & 12.070 \\
\hline Open Markets & 3,369 & 56.808 & 15.986 \\
\hline Government Expenditures as percent of GDP & 4,091 & 16.407 & 8.260 \\
\hline Unemployment & 4,002 & 8.853 & 6.216 \\
\hline Human Development Index & 1,375 & 0.652 & 0.174 \\
\hline Social Support & 1,057 & 0.815 & 0.119 \\
\hline Freedom to Make Life Choices & 1,047 & 0.719 & 0.147 \\
\hline Generosity & 1,004 & 0.001 & 0.164 \\
\hline
\end{tabular}

Table 2. Correlations

\begin{tabular}{|l|c|c|c|c|c|c|c|c|c|c|c|}
\hline Variables* & 1 & 2 & 3 & 4 & 5 & 6 & 7 & 8 & 9 & 10 & 11 \\
\hline 1. SWB & 1.000 & & & & & & & & & & \\
\hline 2. ROL & 0.684 & 1.000 & & & & & & & & & \\
\hline 3. LGV & -0.430 & -0.305 & 1.000 & & & & & & & & \\
\hline 4. REF & 0.497 & 0.678 & -0.003 & 1.000 & & & & & & & \\
\hline 5. OPM & 0.508 & 0.706 & -0.070 & 0.664 & 1.000 & & & & & & \\
\hline 6. GEX & 0.353 & 0.278 & -0.553 & 0.165 & 0.158 & 1.000 & & & & & \\
\hline 7. UNM & -0.150 & -0.092 & -0.108 & 0.047 & 0.014 & 0.165 & 1.000 & & & & \\
\hline 8. HDI & 0.746 & 0.708 & -0.334 & 0.595 & 0.606 & 0.169 & 0.052 & 1.000 & & & \\
\hline 9. SSU & 0.685 & 0.510 & -0.385 & 0.364 & 0.429 & 0.349 & -0.008 & 0.636 & 1.000 & & \\
\hline 10. FLC & 0.533 & 0.499 & -0.179 & 0.348 & 0.308 & 0.047 & -0.333 & 0.359 & 0.456 & 1.000 & \\
\hline 11. GEN & 0.238 & 0.282 & -0.069 & 0.167 & 0.144 & -0.070 & -0.325 & 0.013 & 0.095 & 0.399 & 1.000 \\
\hline
\end{tabular}

*SWB: Subjective Well-being; ROL: Rule of Law; LGV: Limited Government; REF: Regulatory Efficiency; OPM: Open Markets; GEX: Government Expenditures in percentage of GDP; UNM: Unemployment; HDI: Human Development Index; SSU: Social Support; FLC: Freedom to Make Life Choices; GEN: Generosity. 
Table 3. Population-averaged Regression Estimates (Dependent variable: Subjective Well-Being)

\begin{tabular}{|c|c|c|c|c|c|c|}
\hline & $\begin{array}{c}\text { Expected } \\
\text { Sign } \\
\end{array}$ & $\begin{array}{l}\text { Model } \\
(1)\end{array}$ & $\begin{array}{l}\text { Model } \\
(2) \\
\end{array}$ & $\begin{array}{l}\text { Model } \\
(3)\end{array}$ & $\begin{array}{l}\text { Model } \\
(4)\end{array}$ & $\begin{array}{l}\text { Model } \\
(5)\end{array}$ \\
\hline Gov. Exp & + & $\begin{array}{c}0.035^{* * *} \\
(0.008)\end{array}$ & $\begin{array}{c}0.003 \\
(0.008)\end{array}$ & $\begin{array}{c}0.014 \\
(0.008)\end{array}$ & $\begin{array}{c}0.023^{* *} \\
(0.008)\end{array}$ & $\begin{array}{l}0.022 * * \\
(0.008)\end{array}$ \\
\hline Residual Unemp. & - & $\begin{array}{c}-0.022 * * * \\
-0.006\end{array}$ & $\begin{array}{c}-0.021^{* * *} \\
(0.006)\end{array}$ & $\begin{array}{c}-0.023^{* * *} \\
(0.007)\end{array}$ & $\begin{array}{c}-0.026^{* * *} \\
(0.006)\end{array}$ & $\begin{array}{c}-0.029 * * * \\
(0.006)\end{array}$ \\
\hline Residual HDI & + & $\begin{array}{c}3.055^{* * *} \\
-0.303\end{array}$ & $\begin{array}{c}2.296 * * * \\
(0.391)\end{array}$ & $\begin{array}{c}3.080 * * * \\
(0.239)\end{array}$ & $\begin{array}{c}3.040 * * * \\
(0.376)\end{array}$ & $\begin{array}{c}3.197 * * * \\
(0.408)\end{array}$ \\
\hline Social Support & + & $\begin{array}{c}4.069 * * * \\
(0.315)\end{array}$ & $\begin{array}{c}3.071 * * * \\
(0.344)\end{array}$ & $\begin{array}{c}3.924 * * * \\
(0.322)\end{array}$ & $\begin{array}{c}3.623 * * * \\
(0.323)\end{array}$ & $\begin{array}{c}3.582 * * * \\
(0.327)\end{array}$ \\
\hline Free Choice & + & $\begin{array}{c}1.736^{* * *} \\
(0.229)\end{array}$ & $\begin{array}{c}0.883 * * * \\
(0.246)\end{array}$ & $\begin{array}{c}1.671 * * * \\
(0.239)\end{array}$ & $\begin{array}{c}1.387 * * * \\
(0.241)\end{array}$ & $\begin{array}{c}1.579 * * * \\
(0.240)\end{array}$ \\
\hline Generosity & + & $\begin{array}{l}0.436^{*} \\
(0.216)\end{array}$ & $\begin{array}{c}0.135 \\
(0.221)\end{array}$ & $\begin{array}{l}0.434 * \\
(0.213)\end{array}$ & $\begin{array}{c}0.338 \\
(0.219)\end{array}$ & $\begin{array}{c}0.291 \\
(0.223)\end{array}$ \\
\hline Year 2008 & & $\begin{array}{c}0.013 \\
(0.043) \\
\end{array}$ & $\begin{array}{c}0.203 * * * \\
(0.040)\end{array}$ & $\begin{array}{c}0.04 \\
(0.044) \\
\end{array}$ & $\begin{array}{c}0.147 * * * \\
(0.040)\end{array}$ & $\begin{array}{c}-0.09 \\
(0.053) \\
\end{array}$ \\
\hline Year 2009 & & $\begin{array}{l}-0.085 \\
(0.049)\end{array}$ & $\begin{array}{c}0.168 * * * \\
(0.042)\end{array}$ & $\begin{array}{c}-0.046 \\
(0.046) \\
\end{array}$ & $\begin{array}{l}0.088^{*} \\
(0.042)\end{array}$ & $\begin{array}{c}-0.170 * * \\
(0.059)\end{array}$ \\
\hline Year 2010 & & $\begin{array}{c}-0.139 * * \\
(0.044) \\
\end{array}$ & $\begin{array}{c}0.105^{* *} \\
(0.034) \\
\end{array}$ & $\begin{array}{c}-0.116^{* *} \\
(0.041) \\
\end{array}$ & $\begin{array}{c}0.04 \\
(0.034) \\
\end{array}$ & $\begin{array}{c}-0.248 * * * \\
(0.054)\end{array}$ \\
\hline Year 2011 & & $\begin{array}{c}-0.123 * * \\
(0.039)\end{array}$ & $\begin{array}{c}0.153 * * * \\
(0.034)\end{array}$ & $\begin{array}{c}-0.107 * * \\
(0.038)\end{array}$ & $\begin{array}{c}0.049 \\
(0.033)\end{array}$ & $\begin{array}{c}-0.240 * * * \\
(0.051)\end{array}$ \\
\hline Year 2012 & & $\begin{array}{c}-0.107 * * \\
(0.040)\end{array}$ & $\begin{array}{c}0.141 * * * \\
(0.035)\end{array}$ & $\begin{array}{c}-0.120 * * \\
(0.037)\end{array}$ & $\begin{array}{c}0.046 \\
(0.034) \\
\end{array}$ & $\begin{array}{c}-0.226 * * * \\
(0.051)\end{array}$ \\
\hline Year 2013 & & $\begin{array}{c}-0.175^{* * *} \\
(0.048)\end{array}$ & $\begin{array}{l}0.087^{*} \\
(0.043) \\
\end{array}$ & $\begin{array}{c}-0.173 * * * \\
(0.047)\end{array}$ & $\begin{array}{l}-0.007 \\
(0.043) \\
\end{array}$ & $\begin{array}{c}-0.305^{* * *} \\
(0.058)\end{array}$ \\
\hline Rule of Law & + & & $\begin{array}{c}0.022 * * * \\
(0.002)\end{array}$ & & & \\
\hline Limited Govern. & + & & & $\begin{array}{c}-0.014 * * * \\
(0.003) \\
\end{array}$ & & \\
\hline Regulatory Eff. & + & & & & $\begin{array}{c}0.026^{* * *} \\
(0.004)\end{array}$ & \\
\hline Open Markets & + & & & & & $\begin{array}{c}0.015^{* * *} \\
(0.003)\end{array}$ \\
\hline Constant & & $\begin{array}{c}0.491 \\
(0.301) \\
\end{array}$ & $\begin{array}{c}1.185^{* * * *} \\
(0.301)\end{array}$ & $\begin{array}{c}1.990 * * * \\
(0.389)\end{array}$ & $\begin{array}{l}-0.594 \\
(0.386) \\
\end{array}$ & $\begin{array}{c}0.375 \\
(0.322) \\
\end{array}$ \\
\hline N. Obs. & & 652 & 639 & 639 & 640 & 639 \\
\hline N. Groups & & 140 & 137 & 137 & 138 & 137 \\
\hline Wald Chi-Sq & & 477.8 & 554.5 & 668.2 & 435.5 & 426.7 \\
\hline $\mathrm{DF}$ & & 12 & 13 & 13 & 13 & 13 \\
\hline Signif. & & 0.0 & 0.0 & 0.0 & 0.0 & 0.0 \\
\hline
\end{tabular}




\section{Conclusion}

In this article we have investigated the linkage between economic institutions and happiness (subjective wellbeing). We have found that the rule of law, regulatory efficiency and open markets positively affect happiness. On the other hand, we have found that the limited government and happiness in a society are negatively related, which is contrary to our expectations. Although it might be argued that the limited government variable's effect on government expenditures and unemployment may lead to such a result, further empirical research, preferably with larger data sets and more refined measures of the limited government, in this field is needed to make convincing judgments.

\section{References}

1. L. V. Mises, Human Action, Scholars' Edition (Auburn: Mises Institute, 1998)

2. D. Rodrik, A. Subramanian, F. Trebbi, Journal of economic growth, 9(2), 131-165 (2004)

3. D. Acemoglu, S. Johnson, J. A. Robinson, Handbook of economic growth, 1, 385-472 (2005)

4. P. Keefer, S. Knack, The Review of Economics and Statistics, 89(3), 566-572 (2007)

5. D. Rodrik, Second-Best Institutions. American Economic Review, 98(2), 100-104 (2008)

6. C. Bjørnskov, A. Dreher, J. A. Fischer, European Journal of Political Economy, 26(4), 419-430 (2010)

7. M. Rode, B. Knoll, H. Pitlik, Economic Freedom of the World: 2013 Annual Report (Fraser Institute, 2013)

8. H. Pitlik, D. M. Redín, M. Rode, Economic Freedom of the World: 2015 Annual Report (Fraser Institute, 185-202, 2015).

9. UNDP, Human Development Report 1990, (New York: Oxford University Press, 1990)

10. J. D. Gwartney, R. G. Holcombe, R. A. Lawson, Institutions and the Impact of Investment on Growth. Kyklos, 59(2), 255-273 (2006)

11. A. C. Cameron, P. K. Trivedi, Microeconometrics using STATA. (College Station, TX: Stata, 2009) 